\title{
CULTURE
}

๙

\author{
Kaja Zabłocka \\ Maria Curie-SkŁodowska University (UMCS) Lublin \\ kajazab@gmail.com
}

\section{Two Cinematic Portrayals of Teachers: John Keating in Dead Poets Society and Terence Fletcher in Whiplash}

\begin{abstract}
This paper is devoted to two selected teacher figures appearing in American film. John Keating (Dead Poets Society) and Terence Fletcher (Whiplash) are going to be analyzed with regard to their beliefs, their methods, and their impact on students. The introduction refers to the prevailing cinematic image of teachers as heroes who inspire and support their students. Another feature common for many onscreen teachers, including Keating and Fletcher, is their being based on real-life figures.

The first section describes Keating's and Fletcher's beliefs influencing their work. Keating believes his role is to build students' confidence, make them feel they can change the world, and convince them they should seize the opportunities life provides them with. Fletcher is in favor of the view that students should not be praised, but pushed to their limits for the sake of results.

The next part deals with the differences in Keating's and Fletcher's methodologies. Keating aims at replacing a traditional approach to education with demonstration and involving students in practical activities. For Fletcher, maintaining a sense of threat in his students is the key to motivating them.

Finally, the analysis turns to Keating's and Fletcher's impact on their students. Keating's teaching makes his students pursue new interests or manage their personal matters effectively. Fletcher's influence is best reflected by his students' anxiety, exhaustion, and - in some cases - the increased drive to practice.
\end{abstract}

Keywords: teacher, education, methodology, film

\section{Introduction}

This article aims to compare two onscreen figures of teachers, that is John Keating (Dead Poets Society) and Terence Fletcher (Whiplash). One can notice that they definitely have one feature in common - both shape their impressionable students, thus following the 
majority of Hollywood depictions of teachers. With few exceptions, such as Ferris Bueller's Day Off (1986) and Teachers (1984), movies contribute to what Catherine Carter $(2009,68)$ calls the "canonization of teachers in popular culture," that is good teachers "inspiring students through their passion for the subject, their nontraditional pedagogy, their charismatic personalities, and their profound caring." Adam Farhi $(1999,157)$ points to a possible downside of such a portrayal: "[b]y forcing them to compete with their cinematic counterparts, the superteacher myth places an impossible burden on real teachers." According to the critic, the superteacher is an unconventional individual who gains the respect of unruly students and acts without the help of the school administration or coworkers. Superteachers make their allegedly mediocre students excel, but it is usually because these students' talents were overlooked by other, uncaring, teachers. Superteachers, on the other hand, care so much about their students that they help them also in personal matters, often risking their own reputation (Farhi, 1999, 157). The protagonists of Stand and Deliver (1988) and Dangerous Minds (1995) fit this pattern. These movies are examples of how cinematic teachers often stem from real-life characters, but their portrayals are usually polished and embellished, so that they appeal to large audiences.

One of such embellished portrayals can be found in Peter Weir's Dead Poets Society (1989). The film, set in the late 1950s, tells the story of an unorthodox English teacher, John Keating, who breathes new life into Welton Academy, an elite preparatory school. As evidenced in the 10 July 1989 Times Daily article "Real-life Professor Inspires Dead Poets Character," the figure of John Keating was modeled on the screenwriter's teacher, Samuel F. Pickering Jr. However, some observe that "the real-life original of Keating. ...would have real grounds for complaint about cinematic misrepresentation" (Heilman 1999, 419). Professor Pickering does not share Keating's primary idea: "[i]f I thought that I really influenced the lives of students, I might stop teaching. I am not a big enough person for such responsibility" (Henderson, 1992).

The second movie to be covered in this paper is Whiplash (2014), written and directed by Damien Chazelle. Whiplash presents the struggle of a conservatory student, Andrew Neiman (Miles Teller), to win the approval of his intimidating teacher, Terence Fletcher (J K Simmons). In an interview for Blacklist, Chazelle admits that the character of Fletcher is based on a teacher he once had as a student jazz drummer at Princeton High School.

Noticeably, both Keating and Fletcher are modeled on real-life figures. However, the original teachers inspired their students - including the future creators of Dead Poets Society and Whiplash - in different ways. The filmmakers' experiences, in turn, influenced the philosophy and methodology of the cinematic characters.

\section{Beliefs}

If there is one prominent concept that can be associated with Keating, it is carpe diem. In his first lesson in Welton, he tells his students: "Carpe diem. Seize the day, boys. Make your lives extraordinary." He strengthens the message with other literary 
allusions: for example, Robert Herrick's poem To the Virgins, to Make Much of Time or excerpts from Henry David Thoreau. However, the question is whether he himself acts in accordance with this philosophy. On the one hand, he might wish to lead just the life he does: he says that he "love[s] teaching and do[es] not want to be anywhere else." Thus, he "seized the day" to achieve what he did, and continues doing so, in his own understanding. On the other hand, one might argue that Keating does not practice what he preaches: that possibly he considers himself too old to "gather his rosebuds" and spends his far-from-adventurous days on stirring young minds.

Other ideas that Keating advocates are individualism and nonconformity. He warns his students: "Boys, you must strive to find your own voice. Because the longer you wait to begin, the less likely you are to find it at all." He illustrates his point by encouraging them to find their own stride. He quotes Robert Frost with "[t]wo roads diverged in the wood and I, I took the one less traveled by, and that has made all the difference." To him, seeking one's own path should be young people's primary concern - as he tells Nolan, "I always thought the idea of education was to learn to think for yourself." Nolan disagrees, "at these boys' age? Not on your life!" Perhaps Nolan sees thorough education as the basis for making informed life choices. It is for the viewer to decide to what extent they agree with these approaches. It is also for the viewer to ponder how much of individualism and nonconformity one can retain while teaching at an elite school. Some might reach a conclusion that Keating is only talking about individualism, whereas others might see his role at Welton as a genuine act of nonconformity.

In order to think for oneself, one has to leave behind outdated concepts that tie them to the ground. Keating believes that "words and ideas can change the world." Does he really change the world with his words, or does he even try to? Keating shows his students that coursebook clichés should not be followed blindly, by mocking the notion that poetry's greatness is measurable. However, there are not many situations in which he actually tries to change the world with words. He influences particular people, but for some reason is not willing to challenge the hostile schooling system. In his conversations with McAllister and the principal Nolan Keating is not as persuasive as one might expect him to be. Again, it remains ambiguous whether Keating acts the way he claims to be right.

Another idea Keating advocates is that poetry expresses passions common to all humans, not just those artistically inclined. He says: "We write poetry because we are members of the human race." This view is also present in Keating's conversation with McAllister. McAllister warns him: "You take a big risk by encouraging them to be artists, John. When they realize they're not Rembrandts, Shakespeares or Mozarts, they'll hate you for it." Keating replies: "We're not talking artists, George, we're talking freethinkers."

To sum up, Keating believes his students should live their lives to the full, celebrate their individualism, not be afraid to introduce new ideas, and appreciate the power of poetry. The viewer is to consider on their own to what degree Keating is - or possibly was in the past - abiding by the concepts he propagates. 
Fletcher's beliefs might be inferred on the basis of his methodology. Nevertheless, it is more accurate to deliberate on how he presents them to Andrew at the jazz night:

I don't think people understood what it was I was doing at Shaffer. I wasn't there to conduct. Any fucking moron can wave his arms and keep people in tempo. I was there to push people beyond what's expected of them. I believe that is an absolute necessity. Otherwise, we're depriving the world of the next Louis Armstrong. The next Charlie Parker. I told you about how Charlie Parker became Charlie Parker, right?

Andrew knows the story well, so he answers promptly: "Jo Jones threw a cymbal at his head." Fletcher continues:

Exactly. Parker's a young kid, pretty good on the sax. Gets up to play at a cutting session, and he fucks it up. And Jones nearly decapitates him for it. And he's laughed off-stage. Cries himself to sleep that night, but the next morning, what does he do? He practices. And he practices and he practices with one goal in mind, never to be laughed at again. And a year later, he goes back to the Reno and he steps up on that stage, and he plays the best motherfucking solo the world has ever heard. So imagine if Jones had just said: "Well, that's okay, Charlie. That was all right. Good job." And then Charlie thinks to himself, "Well, shit, I did do a pretty good job." End of story. No Bird. That, to me, is an absolute tragedy. But that's just what the world wants now. People wonder why jazz is dying. I tell you, man, and every Starbucks "jazz" album just proves my point, really. There are no two words in the English language more harmful than "good job."

Andrew has some doubts and asks: "But is there a line? You know, maybe you go too far, and you discourage the next Charlie Parker from ever becoming Charlie Parker?" To Fletcher, this is not a reason for concern: "No, man, no. Because the next Charlie Parker would never be discouraged." Andrew is still not convinced, as he replies with "Yeah." As the final defence of his views, Fletcher adds: "The truth is, Andrew, I never really had a Charlie Parker. But I tried. I actually fucking tried. And that's more than most people ever do. And I will never apologize for how I tried."

This conversation provides a first-hand explanation of Fletcher's motives. He believes his role at the conservatory was to push students towards greatness. To Fletcher, no person dreaming of excellence should perceive their decent performance as the end of the road, and a good mentor is to shape such an approach by avoiding praise. The rationale behind him assuming the role of a hero - striving to keep jazz alive - is to be assessed by the audience. Nevertheless, one has to admit the consistency between what Fletcher presents as his aims, the means required to achieve them, and his actions. 


\section{Methodology}

From the beginning, Keating's methods are contrasted with those prevalent at Welton Academy. As Farhi comments, "Chemistry, Latin, and calculus are all presented as deadly boring - the teachers are monotonous, they have no personality. When the audience has been sufficiently dulled, Mr. Keating wanders in, whistling, and leaves" (Farhi 1999, 158). Not only is the subject matter of the first lesson surprising to students, but so is the way of introducing it. Keating tries to get his message across by drawing the boys' attention to the old photographs displayed in the hall. He does not simply say "Carpe diem," but whispers it as if it were actual advice from the alumni in the pictures. This lesson is an example of how Keating rephrases and acts out ideas he wishes his students to ponder on.

Keating also engages his students in unconventional activities. These include, for example, standing on the teacher's desk, after Keating has done so himself and told them to "come, see for [themselves]." They are also asked to compose a poem on their own in order to discover how poetry can help them in self-expression. Some tasks combine Keating's subject with physical exercise - for instance, kicking the ball while exclaiming an assigned line from a poem. Keating explains why physical activity is important: "for me, sport is actually a chance for us to have other human beings push us to excel." Just like poetry, it can lead to better understanding of oneself.

Keating's methodology can be praised for its humanistic orientation, but it has also been criticised for the neglect of academic knowledge or skills. For example, Carter $(2009,72)$ writes:

[Keating's] actual pedagogy is questionable and is elided over by the film's focus on individual
students; viewers never see Keating's content knowledge or his actual classroom technique at
all once the "inspiration" is provided. He requires that his students write poems to express them-
selves but never addresses the thorny issue of grading such work. Even if the viewer accepts
poetry's primary purpose as expression, Keating does nothing with poetry's technical or literary
aspects. He insists that [Todd].... free-associate about Whitman in front of the class, which
reveals Todd's understanding of the poetry in question, but it remains unclear whether this un-
derstanding will be translated into the kind of disciplined effort that will help Todd in college.

Certainly, Keating's curriculum is not orientated on providing the knowledge or skills that will be required in the future to pass particular university exams. However, Keating might realize that English as a school subject is not essential for the prospective doctors, lawyers, and economists. This is why, instead of teaching "technical aspects" the students will most likely not need in their adult lives, he focuses on shaping their self-reliance necessary in said occupations. Viewers cannot be sure whether omitting considerable parts of the coursebook will deter even a single student's plans as to their further education and profession. In that case, they would be more inclined to think that preparing for the university entry exams should be the teacher's priority. 
Some of the accusations apply also to Fletcher: he does not exactly teach skills or knowledge his students need. He demands that they learn and practice on their own. His role is to create the atmosphere he believes is suitable for their development. Fletcher's students are constantly on their toes, mainly because they can never be sure of their future in the band. They know that sooner or later they are going to be shouted at or insulted. What they do not know is whether this will be another tantrum to survive or the end of their career in the band.

Fletcher maintains this sense of threat not only with his intimidating looks and gestures, but also with the language he uses. His invectives often make no sense - as in "I will fuck you like a pig." In an interview for The Dissolve, Chazelle explains:

[t]here's not a single demographic group in existence that he doesn't go after at some point in the movie, but there's almost no logic to it... He's in a room with a group of highly competitive, undersexed, workaholic musicians who are all stepping on each other to get one of the two or three spots available for them, so he's going to use the kind of language - it's the same thing you see in military boot camp - that makes them feel as unmasculine as possible.

Fletcher does not "go after" all demographic groups, but taunts, for example, Ryan's Irish origin ("there's no pot of gold down there") or Metz's weight ("your mind's on a fucking Happy Meal instead of on pitch"). He calls Carl "Mister Gay Pride of the Upper West Side himself," although there is no other hint at him being homosexual.

Fletcher often does not say what his students need to know and leaves them confused. This can be noticed in the first scene, when Fletcher asks Andrew why he stopped playing. Andrew starts again, understanding the question as a suggestion to do so. Fletcher concludes his efforts with: "Did I ask you to start playing again? I asked why you stopped playing and your version of an answer was to turn into a wind-up monkey." Other examples of vague messages are his comments during Andrew's first rehearsal - he limits his feedback to "a little trouble there" and "not quite my tempo."

Many viewers cannot know if Andrew is indeed rushing or dragging, or if it is just another of Fletcher's games. He manipulates his students: for example, by introducing new members and making them compete for a part. It is true that Fletcher is "more bark than bite," as Ryan tells Andrew, and his aggression is mainly verbal. However, he uses physical violence on some occasions - when he hits Andrew in the face or throws a chair at him.

Overall, Fletcher's methodology is far from conveying knowledge, demonstration or constructive criticism. His makes his students anxious with his ambiguous comments and insults. He acts thus in order to ensure that they never feel satisfied with their performance and never stop trying to improve. As Chazelle puts it:

Fletcher's methodology is like if there was an ant on this table, and I wanted to kill it, so I used a bulldozer. Yeah, you kill the ant, but you also do a lot of other damage. And in 
Pobrane z czasopisma New Horizons in English Studies http://newhorizons.umcs.pl Data: 26/04/2023 11:47:35

Two Cinematic Portrayals of Teachers: John Keating in Dead Poets Society...

Fletcher's mindset, that's actually fine. Fletcher's mindset is, "If I have 100 students, and 99 of them are, because of my teaching, ultimately discouraged and crushed from ever pushing this art form, but one of them becomes Charlie Parker, it was all worth it.

\section{Impact on Students}

One of the students Keating influences is Neil Perry. He is introduced as an easygoing, kind, and charismatic top student. Neil's father does not want Neil to be distracted by additional activities such as the school annual, and Neil obeys him. Under Keating's influence, Neil becomes more independent and pursues his passion despite his father's disapproval. It is, however, not a mindless rebellion - Neil remains a diligent student. He dares to do "what's really, really inside [him]," that is to act in a play. Keating's influence is evidenced in Neil's exclamation: "for the first time in my whole life, I know what I wanna do. And for the first time, I'm gonna do it. Whether my father wants me to or not. Carpe diem!" Whereas pursuing one's dreams can be praised, Neil's way of dealing with his father's disapproval is inappropriate. By fabricating a letter from his father to headmaster Nolan, Neil closes the door on a positive resolution. When his father finds that Neil has disobeyed him, he is not so much discontent with Neil's participation in the play as infuriated with Neil's deception. Keating urges Neil to try and convince his father that acting is his passion. The next day, Keating asks Neil about the outcome of the confrontation and Neil lies to him. Keating seems to have doubts but does not enquire further or take any action that would prevent Neil's suicide. If it is true that he ignores his suspicions, then that might be his most serious fault.

Keating's influence on Todd Anderson is not that ambiguous. At the beginning, Todd is shy and appears to have lived in his brother's shadow his whole life. He is afraid of speaking in the presence of his classmates and refuses to read aloud during the Society's meetings. He does not want Neil to read his poem and fakes being unprepared for the lesson to avoid further embarrassment. Keating forces Todd to improvise poetry in front of the entire class, which seems to be a breakthrough for Todd in coping with his anxiety. He gradually becomes less concerned with his parents' opinion. Together with Neil, he makes fun of the thoughtless birthday present from them. He is not afraid of expressing his doubts when he meets his parents in Nolan's office. All in all, Todd develops courage thanks to Keating: he is the only one known to defend Keating from false accusations, and is the first to stand on his desk to show respect to him.

Knox Overstreet is influenced by Keating in a different way. He meets the perfect girl, Chris, and because she is "practically engaged," he admits that his infatuation is a tragedy. It is presumably thanks to Keating that he realizes he does not want to "lead a life of quiet desperation," so he goes on a bike ride just to see Chris. Interestingly, he also encourages himself by saying "Carpe diem": before calling Chris and before kissing her. When Knox offers Chris an agreement, he promises on "Dead Poets' honor." 
Thus, Keating's impact on Knox is visible in Knox's determination to be with Chris, but also in the way he talks with her and about her.

Charlie Dalton seems to misunderstand Keating's message. His answers to Keating's questions are dismissed with "Thank you for playing, mister Dalton." Charlie anonymously publishes an article in Welton Honor to fight for the noble cause of making the Academy coeducational. Unfortunately, Keating calls his staging of a call from God "a pretty lame stunt." Keating tells Charlie, "sucking the marrow out of life doesn't mean choking on the bone. Sure, there's a time for daring and there's a time for caution." Considering that Keating has not spoken about the boundaries to self-expression before, Charlie's only fault is the literal enactment of Keating's concepts. Charlie tries to change the world with words, even if it is the micro-universe of Welton Academy. Thus, Charlie might have learnt more from Keating than it would seem.

Thanks to Keating, the Dead Poets Society is reactivated. The boys discover a mention of it in an old school annual and ask Keating about the society. He is reluctant to reveal the secret at first, because he "doubt[s] the present administration would look too favorably upon that." Yet he starts to describe the magical atmosphere of the meetings and places a copy of Five Centuries of Verse in Neil's room. The society's meetings are criticized by Roger Ebert: "in its reincarnate form [the society] never generates any sense of mystery, rebellion or daring. The society's meetings have been badly written and are dramatically shapeless." (Ebert 1989) No matter to what degree, if at all, the viewer is enchanted by the depiction of the society's meetings, it is clear that the participants find them entertaining. They bond while reading poetry, telling horror stories or talking about their problems.

Keating's inspiration to a group of students is the focus of the movie. Notably, the rest of the boys are indifferent to or skeptical about Keating's methods and do not wish to cooperate, for example, when Hopkins proudly recites his poem: "the cat sat on the mat." The contrast between those who are inspired - and those who are not - is made particularly visible in the last scene, when many remain seated. The scene is meant to show the boys' loyalty to Keating, but a crucial question needs to be asked: is the students' respect for Keating genuine? As Farhi observes, they "all signed a document implicating him in [Neil's] suicide." (Farhi 1999, 159) This is why the final scene might appear untrue. However, one should remember that Keating told his students not to miss their opportunities. They might have realized that they cannot defend Keating at all costs, because "being expelled from school is not daring, it's stupid." Thus, complying with Nolan's requirements can be read as a proof that they fully understood the lesson Keating tried to teach them.

Whereas Dead Poets Society tells the story of the teacher's influence on aspiring intellectual elites, Whiplash centers around teacher's influence on an aspiring drummer, Andrew Neiman. It is suggested that Andrew was fascinated by Fletcher, the said teacher, before they even met: when he tells his father "he saw me play," his father understands the reference. From his first encounter with Fletcher, Andrew feels the need to impress him, so he starts practicing more. His efforts seem to be appreciated when 
Fletcher selects him as the only person from the Nassau Band. Even more surprisingly, Fletcher exclaims "we've got Buddy Rich here!" minutes into Andrew's debut in the Studio Band. Andrew's morale has just been boosted by Fletcher's affirmations that "[Andrew is] there for a reason," and "the key is to relax." It soon turns out that Fletcher's compliments are part of the game designed to deprive Andrew of confidence. Fletcher humiliates Andrew and abuses his trust by referring to their conversation, calling him "worthless, friendless, faggot-lipped piece of shit whose mommy left daddy when she figured out he wasn't Eugene O'Neill." Andrew reacts by doing what Fletcher told him to do: he practices harder. He feels that his advancement to being a core member is well-earned and becomes more self-centered and condescending towards those who are not core members of the Studio Band.

Fletcher soon shows Andrew that his place in the band is not certain - by appointing Ryan the new core drummer. This outrages Andrew: believing that he is better, he takes out his frustration on Ryan. Demotion propels Andrew to practice so hard that blood drips from his palms. He shows his determination to pursue a music career by breaking up with his new girlfriend. As Chazelle puts it, "[i]t [is] weirdly indicative of Andrew's state of mind that he has this whole speech to this girl ... that, to me, [is] really him becoming a mini-Fletcher." Andrew is so desperate to convince Fletcher that he deserves the part, that he strives to drum so fast as to achieve "perfect 400s," even when Fletcher does everything to distract him. On another occasion Andrew tries to prove his worth to Fletcher again by walking onto stage right after he had been in an accident. Such a feat is unwise, not only because Andrew risks his health, but also because he is likely to spoil the whole band's performance in his condition. Andrew is so infuriated with Fletcher's decision to dismiss him that he physically attacks Fletcher and is later expelled from school for this outburst. Thus, Fletcher indirectly causes Andrew's loss of a chance to graduate from the prestigious conservatory. Andrew seems to be ultimately discouraged: he throws away all the things reminding him of drumming and testifies against Fletcher. However, the conversation at the club changes Andrew's views, so he decides to return to drumming and participate in JVC Jazz Festival. After a temporary surrender, Andrew remembers that "Charlie Parker would never be discouraged." Once more, he shows his determination: he returns for a stunning performance - which grants him long-awaited praise from Fletcher.

Another student known to have been deeply affected by Fletcher is Sean Casey. Sean was a mediocre student at Shaffer, but Fletcher "saw a drive in him" and gave him a chance to be in the Studio Band. There is no mention of the methods Fletcher used in his work with Sean, but they are likely to have been similar to those applied to Andrew. Sean succeeded in pursuing a career and committed suicide six years after leaving the band, due to lasting anxiety. Sean's example is an indication that Fletcher's methodology can be dangerous - as his influence on students cannot be fully predicted.

Some members of the band are discouraged. For instance, Carl Tanner "switche[s] to pre-med." Carl is another victim of Fletcher's games and, like Andrew, is nervous and manifests his superiority while being a core member of the band. The other drummer, 
Ryan, is the only one able to distance himself from Fletcher's manipulations. He tells Andrew not to worry about Fletcher and appears not to blame himself for Fletcher's moods.

The movie does not focus on other members of the band. They are shown exhausted from practice, hostile towards Andrew (“don't fucking touch my folder, man") and not sociable. This is probably due to the tense atmosphere Fletcher creates and the high competitiveness within the elite Studio Band.

\section{Conclusion}

Whereas the differences between Keating and Fletcher are easy for the audience to observe, there are also similarities between these two teachers in all mentioned aspects: their beliefs, their methods, and their impact on students. Both Keating and Fletcher are idealistic, but while one praises individualism, the other puts individualism aside for the sake of another ideal, that is music. They both feel the teacher's role is to create an atmosphere suitable for their students' development - Keating uses positive motivation to encourage his students to think for themselves, and Fletcher uses negative motivation to make his students practice harder. Neither of them explains in detail, nor demonstrates, useful knowledge and skills. Keating's students become self-confident, pursue their interests, fight for love, and bond with one another. Fletcher's students become anxious, are obsessed with practicing, and neglect love and friendship. Keating's influence can be opposed with that of Fletcher's by summarizing the former as broadening students' horizons, and the latter, as narrowing them. However, in neither case the impact is clearly positive or clearly negative.

Notably, both Keating and Fletcher work in elite, all-male environments, so they are not exactly stereotypical superteachers who fight for the disadvantaged. And yet Keating lives on as the embodiment of a cinematic "great teacher" for his highlighted characteristics, such as being unconventional and caring about his students. Fletcher, in turn, has been compared to mentors present in military or sports movies (Robinson 2014). However, his figure represents a vital issue in modern education. As Tallerico (2014) writes, "we're in an era of praise, where encouragement is the teaching tool and every kid gets a medal for participation. Have true talents been left to wither because they were over-watered?" Presumably, there will be other movies which present education from this perspective - as well as other movies depicting the mythical superteacher.

\section{References}

Carter, Catherine. 2009. "Priest, Prostitute, Plumber? The Construction of Teachers as Saints." English Education, vol. 42, no. 1 (October): 61-90.

"Damien Chazelle interview, Blacklist." Accessed January 14, 2016. http://gointothestory. blcklst.com/2014/10/interviewvideo-damien-chazelle-whiplash.html. 
Pobrane z czasopisma New Horizons in English Studies http://newhorizons.umcs.pl Data: 26/04/2023 11:47:35

Two Cinematic Portrayals of Teachers: John Keating in Dead Poets Society...

Ebert, Roger. 1989. “Dead Poets Society Review.” June 9. Accessed January 14, 2016. http:// www.rogerebert.com/reviews/dead-poets-society-1989.

Farhi, Adam. 1999. "Hollywood Goes to School: Recognizing the Superteacher Myth in Film." The Clearing House, vol. 72, no. 3 (January - February): 157-159.

Heilman, Robert B. 1991. "The Great-Teacher Myth." The American Scholar, vol. 60, no. 3, 417-423.

Henderson, Bill. 1992. "Robin Williams and Then Some." The New York Times, January 12. Accessed January 14, 2016. http://www.nytimes.com/1992/01/12/books/robin-williams-andthen-some.html. "Real-life Professor Inspires 'Dead Poets' Character." 1989. Times Daily, July 10. Accessed January 20, 2017. https://news.google.com/newspapers?id=oGoeAAAAIBAJ\&sjid=ZMgEAAAAIBAJ\&pg=5548,1862015\&hl=en.

Robinson, Tasha. 2014. "What Is and Isn't Ambiguous About Whiplash." The Dissolve, October 15. Accessed January 14, 2016. https://thedissolve.com/features/emerging/787-damien-chazelle-on-what is-and-isntambiguous-abou/.

Scull, W. Reed and Gary L. Peltier. 2007. "Star Power and the Schools: Studying PopularFilms' Portrayal of Educators." The Clearing House, vol. 81, no. 1 (September - October): 13-18.

Tallerico, Brian. 2014. "Whiplash Review." October 10. Accessed January 14, 2016. www. rogerebert.com/reviews/whiplash-2014. 